\title{
Rektumda siyah noktasal görünüm
}

\author{
Black spot view at rectum
}

Hakan Ümit ÜNAL ${ }^{1}$, Ümit SEÇMEN², Murat KORKMAZ³, Uğur YILMAZ

Başkent Universitesi Istanbul Hastanesi, ${ }^{1}$ Gastroenteroloji Kliniği, ${ }^{2}$ Genel Cerrahi Kliniği, Istanbul

Başkent Üniversitesi Ankara Hastanesi, ${ }^{3}$ Gastroenteroloji Kliniği, Ankara

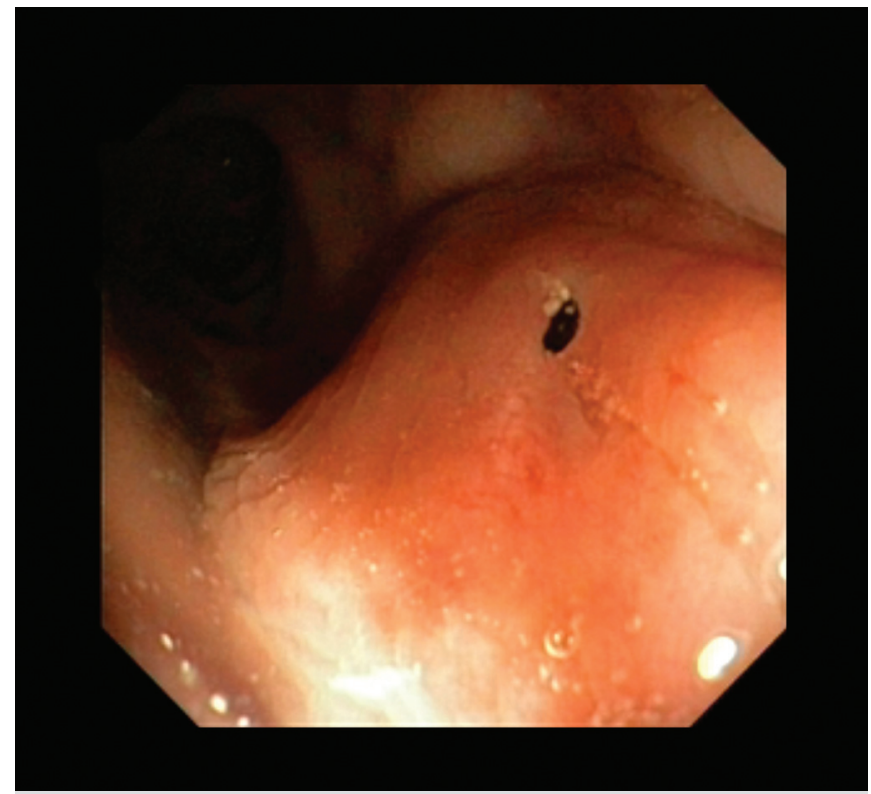

Resim 1. Rektum arka duvarda ortası siyah, çevresi kabarık ve sert lezyon.

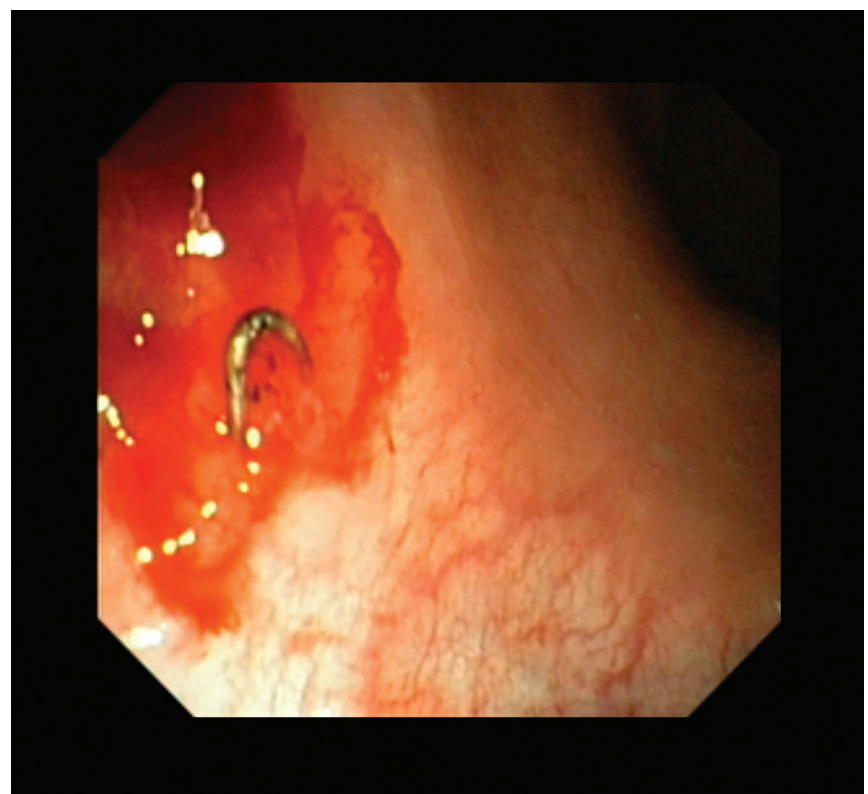

Resim 2. Mukozaya saplanmış metal cisim.

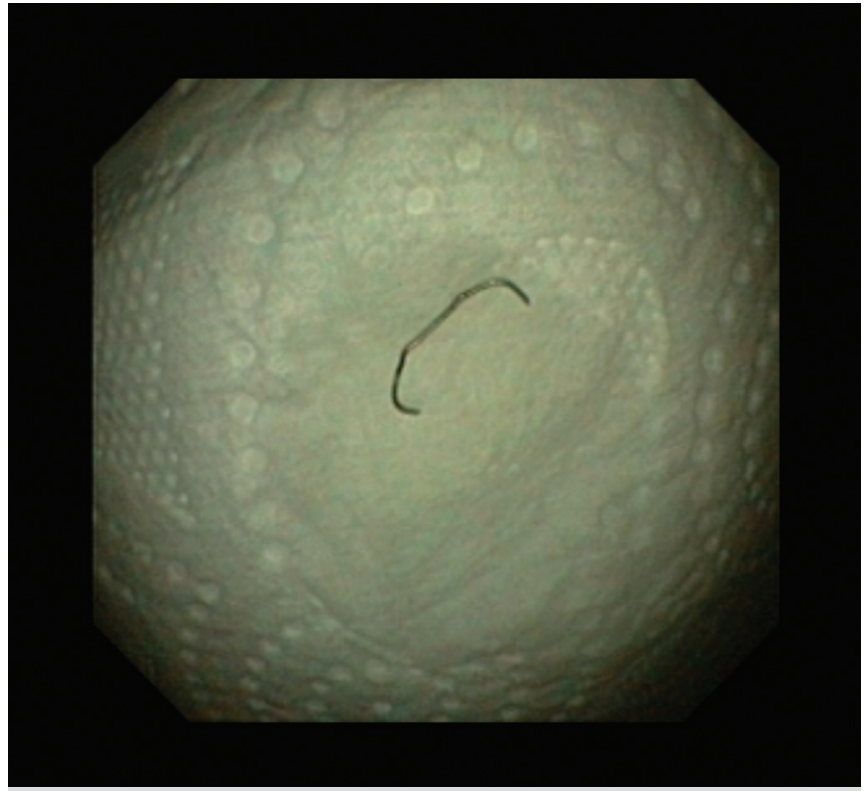

Resim 3. Dışarıya alınan metal cisimin bir zımba teli olduğu anlaşıldı.

Hipertansiyon ve tip 2 diabetes mellitusu olduğu bilinen ve 4 yll önce sistosel ameliyatı olmuş olan 67 yaşında bayan hasta. Son bir yıldır olan ve zamanla daha da belirginleșen kabızlık şikayeti ile başvurdu. Anamnezinde gaitayı son kısımdan dışarı atmakta zorluk çektiği şeklinde ifadesi olan hastanın gelişinde yapilan sistemik muayenede patolojik bulgu saptanmazken rektal dijital muayenede rektumda arka duvarda mukozal kabarıklık ve endurasyon saptandı. Kan bulaşı yoktu. Gaita forme ve normal renkte idi. Yapılan kolonoskopik incelemede rektum arka duvarda mukozadan hafif kabarı ortası siyah lezyon izlendi (Resim 1).

Ön tanınız nedir? 


\section{CEVAP}

Tariflenen lezyondan biyopsi alınırken forsepse metal bir cismin dokunduğu hissedildi. Forseps ile tutularak traksiyon uygulandığında zımba teli olduğu izlendi (Resim 2, 3). Zımba telinin çıkarıldığı bölgeden alınan biyopsiler yabancı cisim reaksiyonu ile uyumlu idi. Hastanın takibinde aylar içerisinde şikayetlerinde belirgin gerileme oldu. Anamnestik olarak hasta zımba teli yuttuğunu hatırlamıyordu. Genel cerrahi ve kadın hastalıkları uzmanlarına danışılarak metal cismin ameliyat materyali olma ihtimali dışlandı. Sonuç olarak sık sık poşet çay içen hastada zımba telinin çay poşetinden çay içerisine düştükten sonra yutulmuş olabileceğini düşündük. 